\title{
Un estudio educativo sobre el efecto del consumo de energía en la productividad del capital en el sector agrícola por el método ARDL (estudio de caso de Irán)
}

\section{An educational study on the effect of energy consumption on capital productivity in the agricultural sector by the ARDL method (an Iran case study)}

\author{
Maryam Keshavarziyan $^{1 \mathrm{a}}$, Azadeh Dabbaghi ${ }^{2}$ \\ Research Institute of Petroleum Industry (RIPI), Iran ${ }^{12}$ \\ D Orcid ID: https://orcid.org/0000-0003-0745-2782 1 \\ (iD) Orcid ID: https://orcid.org/0000-0001-9476-0067²
}

Recibido: 15 de abril de 2020

Aceptado: 18 de octubre de 2020

\section{Resumen}

El presente documento investiga los efectos del consumo de energía en la productividad del capital utilizando la producción de travesaños en el sector agrícola de Irán, mediante el método econométrico apropiado, que es el retraso distribuido autorregresivo (ARDL). Asimismo, el método de esta investigación es descriptivo y utiliza métodos relacionados con los objetivos. Los hallazgos muestran que la relación de consumo de energía per cápita en la relación a largo plazo es $-3,8$, lo que significa que la productividad del capital disminuye alrededor del $4 \%$ para un aumento del uno por ciento en el consumo de energía per cápita. En este estudio, los factores que afectan la productividad energética se han estudiado en el sector agrícola durante 1990-2016 en Irán. En este sentido, la productividad energética se calculó primero utilizando un indicador de productividad parcial. Los resultados revelaron que la productividad energética en el sector agrícola aumentó en promedio $1,1 \%$ por año durante el período de estudio. El promedio de la fuerza laboral por unidad de capital y el capital humano promedio por unidad no afecta la productividad del capital, por lo que el consumo promedio de energía por unidad de capital afecta la productividad del capital.

Palabras clave: Consumo de energía, productividad del capital, agricultura, economía

\footnotetext{
Abstract

This paper investigates the effects of energy consumption on capital productivity using transom production in the agricultural sector in Iran through an appropriate econometric 
method, and autoregressive distributed lag (ARDL). The method of this research is descriptive and using methods related to the objectives. The findings show that the per capita energy consumption ratio in the long-term relationship is -3.8 , it means that the capital productivity decrease about $4 \%$ for one percent increase in per capita energy consumption. In this study, the factors affecting energy productivity have been studied in the agricultural sector during 1990-2016 in Iran. In this regard, energy productivity was first calculated using a partial productivity indicator. The results revealed that energy productivity in the agricultural sector increased by average $1.1 \%$ per year during the study period. The average of labor force per unit of capital and the average human capital per unit of capital is Affectless on the capital productivity, so the average energy consumption per unit of capital effect on capital productivity.

Keywords: Energy consumption, capital productivity, agriculture, economics

\section{Introduction}

Agriculture as an economic section has been played a vital role in employment in the world. Human life is very much influenced by the products of this sector. So the relationship between energy consumption and its impact on capital has an important effect on the improvement of the agricultural sector (Ahmadim, 2013). According to the increasing importance of food supply in countries and the vital role of the agricultural sector in this field and the more important role of this sector in production, exports and employment, as well as the development of the agricultural sector as a prerequisite and essential need for economic development founded the special importance (Aghayi, and Rezagholozadeh, 2015).

In the agricultural sector energy has been considered as one of the most important inputs in order to production. It also can be considered as a bridge to move from traditional agriculture to industrial agriculture (Khalilian and Teymouri, 2016). Energy carriers were initially widely used in industry, but with the advancement of technology as well as the production of equipment to provide services in different sectors, including agriculture, they were able to show their role as a factor in the production of goods and services (Akbari, 2013). The aim of this study was to investigate the effect of the energy consumption on capital productivity by ARDL technique in agriculture sectors among selected provinces of the country. 


\section{Theoretical foundations}

\section{Concepts and basics of productivity}

Productivity is an economical and management concept that is defined as: the amount of goods or services produced in comparison of each unit of energy or labor expended without reducing quality. In other words, productivity is the maximum possible profit by using and optimally using labor, power, talent and skill of labor force, land, machinery, money, equipment, time, place, etc. in order to improve the society welfare. Productivity refers to the work that has carried rather than the work done (Arman, 2015). These attempts can be named obtaining maximum productivity. In deeper concepts, productivity is equated with efficiency, in addition to effectiveness; it implies acting rationally, because just doing the right things is not enough. Rather, it is needed to carry the right thing logically and as expected, and productivity is the hybrid impact of these two factors (Soheili, 2017).

On the other hand, we are talking about the relationship between the system inputs (system / organization) and its outputs (products) in the productivity discussion. So, a change in the value of each of these can influence productivity. Among the different factors affecting productivity, two groups play the vital role: internal factors (hardware factors including: product, machinery, etc. and software factors including specialized people, organization, etc.) and external factors (structural factors, including: economic changes, etc. resources including: human resources... and factors associated to productivity, including: performance and productivity of governmental agencies, etc.) (Azam, 2015).

\section{Productivity indicators}

Productivity in the general concept refers to the output/ data ratio. In other words, productivity refers to the mean production per unit of total inputs, so that if the mean output per unit of inputs increased, it means increased productivity and vice versa means reduced productivity. In general, productivity indicators are assigned into two categories: partial productivity indicators and total productivity indicators. In partial productivity indicators showed the relationship between the output and input, so the relationship between the output and the whole input in the productivity indicators of all factors of production is examined (Krueger, 2014). 


\section{Partial productivity indicators of production factors}

These indicators are obtained by dividing the value added by a certain amount of input, and in order to exclude inflation, it needed to use value added at a fixed price in the base year (Krueger, 2014).

\section{Productivity indicators of total production factors (TFP)}

The productivity indicators of total factors (labor and capital together) show the output/ input ratio. In fact, it shows the mean production per unit of total production factors. This indicator shows the results of changes in labor productivity and capital (Krueger, 2014).

\section{Factors affecting the productivity of total production factors}

It is considered that the productivity growth of all production factors is equal to the Average weight of labor and capital productivity growth of, as a result the factors such as increase the quality level of labor and capital, better allocation of resources and optimal use of available resources and facilities helps to increase the productivity of all factors of production (Krueger, 2014). According to Asian Productivity Organization (APO) report, training and education of the labor force, productivity and knowledge management, foreign investment are the most important factors accelerating the productivity growth of production factors.

\section{Capital productivity indicator}

The concept of capital productivity indicator is that each dollar of capital has created several dollars of added value. This indicator is obtained by dividing the value added by the capital inventory value (at a fixed price). Usually in calculating this indicator, first the value added and the capital inventory value are converted to the fixed prices of the base year, and after dividing the added value into the capital inventory, the capital productivity is obtained (Krueger, 2014).

\section{Research background}

Naji et al (2014) in a study examined the efficiency and productivity of energy in different economic sectors and also estimate the input and price elasticity of energy in 
agriculture, industry and transportation by the method of multi-stage Least Squares method over time 1970-1990. In their paper, they investigate some indicators of energy consumption including the energy intensity indicator. The results estimate the upward trend of the energy intensity indicator in all sectors during the period under review and the downward trend in energy productivity, which is the inverse of the energy intensity indicator.

Khalilian and Rahmani (2016) have examined the factors affecting labor productivity in Iran's agricultural sector. In this study, macroeconomic statistics for the years 1974-2008 have been used. The results show that labor productivity is upward in this sector. Nofarasati (2018) have studied the factors affecting the growth rate of labor productivity in the agricultural sector of Iran during 2000-2020. The study findings showed that the main reason for the increase in labor productivity growth rate can be associated to the relative increase in productivity of total production factors and the effect of total Substitution.

Akbari (2013) in a study entitled "investigation of productivity growth in the agricultural sector of Iran" have measured the productivity growth of total factors of production in the agricultural sector of Iran during 1966-2000. The results of measuring productivity growth and output growth showed that the mean growth of productivity and output growth in the agricultural sector during the study period is 2.6 and 4.8, respectively.

Aghayi, and Rezagholozadeh (2015), examined the long-term and short-term relationship between energy consumption and value-added growth in various economic sectors using the multivariate panel error correction model (PECM) and the Cointegration test and panel causality. The results show that the increase (decrease) in energy consumption in different sections of the country leads to an increase (decrease) in the growth of value added in them. Azam, et al. (2015), examined the causal relationship between energy consumption and economic growth in five member countries of the ASEAN group such as Indonesian, Malaysia, Thailand, Singapore and the Philippines. The results of the study showed that there is a significant and long-term relationship between energy consumption and economic growth among these countries. 


\section{Research area}

The statistical population consisted of this study including selected provinces in the entire agricultural sector of Iran. Provinces with high share of wheat production have been selected in the study. The scope of this research is the available information published for 25 years during 1990-2016 in the country. Time series data used is from Agricultural Bank databases and Statistics Center and Central Bank of Iran. Value-added statistics from Iran's national accounts have been collected at current and constant prices in 1997, published by the Central Bank of the Islamic Republic of Iran. The Ministry of Energy is statistics reference of price and the amount of energy consumed, including diesel oil $\mathrm{s}$ and electricity. The statistics of labor force working in the agricultural sector are collected from the EAO website.

\section{Methodology}

\section{Definition of Translog production Function}

The Translog production Function first proposed by Christensen (Jorgenson \& Lau, in 1972), proposed all the features of a Translog production Function. Another feature of this function is that it allows elasticity of substitution and elasticity of production changes depending on the level of consumption of inputs. In addition, the first derivative of this function has no limit in terms of sign. In other words, Translog Function shows all three production areas, and the final Production in it is increasing decreasing or negative (Hatirilig, 2005). .In the Translog production Function, the coefficients of the interaction of the variables are also estimated in addition to the parameters of the main variables. The following form of this function for the production input $\mathrm{N}$ is as follows: (Krueger, 2014).

$$
\ln Q=\ln \propto+\sum_{i=1}^{n} \beta_{i} \ln x_{i}+\frac{1}{2} \sum_{i=1}^{n} \sum_{j=1}^{n} \gamma_{i j} \ln x_{i} \ln x_{j}
$$

\section{Autoregressive Distributed Lags Method (ARDL)}

Although the use of traditional methods in econometrics is based on the assumption of stability of variables for experimental studies, however, the researches show that many 
time series are unstable, which leads to spurious regression and, finally the confidence in the coefficients will be lost. Therefore, , it is necessary to use methods based on the Cointegration theory in estimating functions when using time series that pay attention to the issue of stability and Co-integration investigates the long-term relationship between variables without any preconditions about the Accumulation degree of variables. This method gives unbiased estimates of long-term coefficients e. Unlike other common techniques in co-integration analysis method, such as the Engle Granger method, there is no need first know the degree of co-integration e of the variables under study. Also, ARDL method is able to simultaneously estimate the long-term and short-term coefficients of the model and determine the direction of causality between the variables of the model.

A simple ARDL pattern is shown below:

$$
\alpha(L, P) Y_{t}=\alpha_{0}+\sum_{i=1}^{k} \beta_{i}\left(L, q_{i}\right) X_{i t}+\delta W_{t}+u_{t}(Y)
$$

Where $\alpha_{0}$ is the constant value, $Y_{t}$ is the dependent variable, and $\mathrm{L}$ is the lag operator. $W_{t}$ Is the non-random variables such as intercept, trend variable, dummy variable or exogenous variables, or fixed $\mathrm{i}$ lag. $\mathrm{P}$ is the number of lags used for the dependent variable, $q_{i}$ is the number of lags for the independent variables. There are two steps to estimate the ARDL model. In the first step, the number of ARDL lag is determined based on one of the Akaike, Schwartz- Bayesian, and Hannan-Quinncriteria, and in the second step the selected pattern is estimated by normal least squares method. Eviews 6 and Microfit 4.1 econometric software have been used to estimate the model (Krueger, 2014).

\section{Introducing the model of factors affecting capital productivity}

The variables of capital productivity, labor, human capital and energy consumption are used to investigate the effect of energy consumption on capital productivity in the agricultural sector. The following equation has a linear form and is a type of translog production function. 


$$
\begin{aligned}
& \operatorname{Ln}(\mathrm{Q} / \mathrm{K})=\beta 0+\beta_{1} \ln (\mathrm{L} / \mathrm{K})+\alpha_{2} \ln (\mathrm{H} / \mathrm{K})+\alpha_{3} \ln (\mathrm{E} / \mathrm{K})+\alpha_{4} \ln (\mathrm{L} / \mathrm{K}) \ln (\mathrm{H} / \mathrm{K})+\alpha_{5} \ln (\mathrm{L} / \mathrm{K}) \ln (\mathrm{E} / \mathrm{K}) \\
& + \\
& \alpha_{6} \ln (\mathrm{H} / \mathrm{K}) \ln (\mathrm{E} / \mathrm{K})+1 / 2 \alpha_{7}(\ln (\mathrm{L} / \mathrm{K}))^{2}+1 / 2 \alpha_{8}(\ln (\mathrm{H} / \mathrm{K}))^{2}+1 / 2 \alpha_{9}(\ln (\mathrm{E} / \mathrm{K}))^{2}
\end{aligned}
$$

Where in

-Q / K capital productivity or average production per unit of capital consumed - L / K average labor force per unit of capital

$\cdot \mathrm{H} / \mathrm{K}$ is average human capital per unit of capital

$\cdot \mathrm{E} / \mathrm{K}$ is average energy consumption per unit of capital

\section{Capital productivity}

Productivity shows the activity efficiency; on the other hand, it evaluates the role of productivity in obtaining the desired goal. Productivity is divided into two parts based on definition Effectiveness and efficiency. Effectiveness determines how much of the planned activity has been accomplished and the planned results have been achieved. In efficiency, the relationship between the result and the used resources is examined. In other words, productivity is the simultaneous realization of efficiency and effectiveness. In this paper, capital productivity is obtained by dividing the added value into capital in the agricultural sector. As can be seen in the chart below, the productivity of capital has generally reduced during 1990- 2015 years (Krueger, 2014).

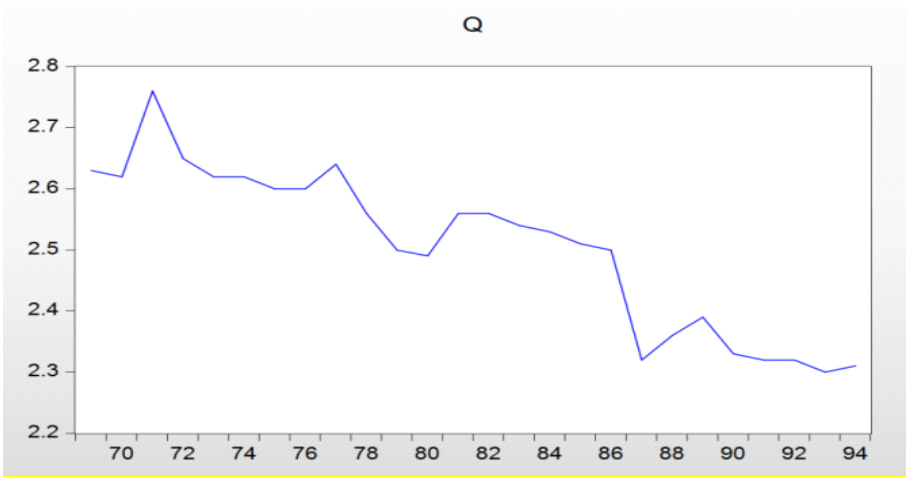

Figure 1

Average production trend per unit of capital

(Source: Iran Statistics Center report) 


\section{Estimation steps : \\ Investigating the static stability of variables}

The use of traditional and conventional econometric methods in estimating coefficients using serial data is based on the assumption that model variables are stable. If the time series variables used in estimating the coefficient are unstable, there may be no relationship or concept between the variables, so that the researcher reach inaccurate inferences about the relationship between the variables. The presence of unstable variables in the model in any case can cause the normal $\mathrm{t}$ and $\mathrm{F}$ tests to be invalid and the resulting regression to be a pseudo regression. In a time, series variable, if its mean, variance, and covariance are independent of the time, that variable is Stationary is, or more accurately, the covariance Stationary. The following generalized Dickey-Fuller method is used to investigate Stationary in a time series variable.

In this study, the absolute value of the generalized Dickey-Fuller statistic is smaller than the critical values for all the variables under study, so the $\mathrm{H}_{0}$ hypothesis that is the unit root of these variables is at a high level of Confidence is confirmed. Then, the generalized Dickey-Fuller test is repeated for the first difference of the variables to determine the degree of accumulation of the desired variables. The results of the generalized DickeyFuller show that some variables become Stationary in first difference, in other words, they are Stationary from degree one degree I (1), but there are some other variables that are Stationary from degree zero f I (0) (table1). 


\section{Table 1}

The results of model reliability test

\begin{tabular}{lcl}
\hline Variable & Explanation & Mania test \\
\hline $\mathrm{Q}$ & $\mathrm{Ln}(\mathrm{Q} / \mathrm{K})$ & $\mathrm{I}(0)$ \\
$\mathrm{E}$ & $\mathrm{E} / \mathrm{K}$ & $\mathrm{I}(1)$ \\
$\mathrm{E}^{2}$ & $\left(\frac{E}{K}\right)^{2}$ & $\mathrm{I}(1)$ \\
$\mathrm{H}$ & $\mathrm{H} / \mathrm{K}$ & $\mathrm{I}(1)$ \\
$\mathrm{H}^{2}$ & $\left(\frac{H}{K}\right)^{2}$ & $\mathrm{I}(1)$ \\
$\mathrm{HE}$ & $\left(\frac{H}{K}\right) \times\left(\frac{E}{K}\right)$ & $\mathrm{I}(0)$ \\
$\mathrm{L}$ & $\left(\frac{L}{K}\right)$ & $\mathrm{I}(0)$ \\
$\mathrm{LE}$ & $\left(\frac{L}{K}\right) \times\left(\frac{E}{K}\right)$ & $\mathrm{I}(0)$ \\
$\mathrm{LH}$ & $\left(\frac{L}{K}\right) \times\left(\frac{H}{K}\right)$ & $\mathrm{I}(0)$ \\
$\mathrm{LL}$ & $\left(\log \left(\frac{L}{K}\right)^{2}\right)$ & $\mathrm{I}(0)$ \\
\hline
\end{tabular}

Source: Author's calculations

\section{Results}

\section{Model estimation}

Now the ARDL model used to estimate the desired function. In this model, there is no precondition to investigate the long-term relationship between the variables for the degree of cointegration. Also, this method carried out long-term and short-term economic analysis. The Hannan-Quinn indicator is used to select the optimal lag in the above model. (Figure2)The optimal lag is selected based on the mentioned criteria $(2,0,0.0,0,0,0,0$, $0,0$, and 0$)$. (Table 2).

\section{Table 2}

Optimal interruption selection

\begin{tabular}{lllllll}
\hline Model & LogL & Alc & BIC & HQ & $\begin{array}{l}\text { Adj.R- } \\
\text { sq }\end{array}$ & Specification \\
\hline 1 & 58.532163 & - & - & - & 0.944812 & ARDL $(2,0,0,0,0,0,0$ \\
& & 3.794347 & 3.156234 & 3.625056 & & \\
2 & 53.040426 & - & - & - & 0.920052 & $\operatorname{ARDL}(1,0,0,0,0,0,0$ \\
& & 3.420035 & 2.831009 & 3.263766 & & \\
\hline
\end{tabular}

Source: Author's calculations 


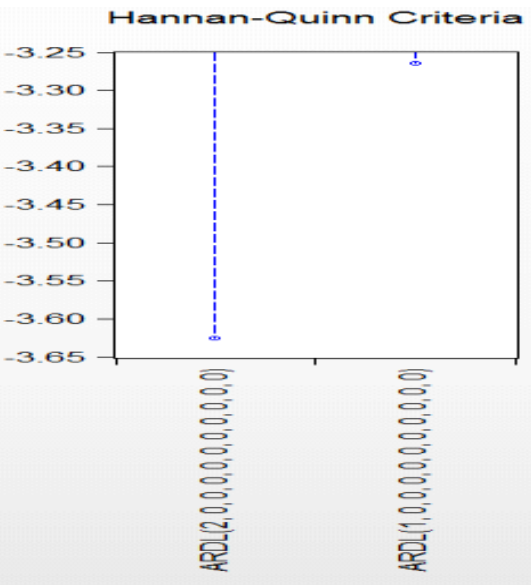

Figure 2

Optimal interruption selection

Source: Author's calculations

According to considering the maximum of two lags, after estimating of the dynamic linear model of capital productivity in the agricultural sector, the following results were observed. The results of estimating the dynamic model by ARDL method show that the coefficient of average labor force per unit of capital variable and average human capital per unit of capital is statistically insignificant, which show the no significant effect of these two variables to capital productivity.. The coefficient of average energy consumption variable for each unit of capital is statistically significant. In other words, this variable has a significant effect on capital productivity.

Also, the LE and HE coefficients were not statistically significant, so these two variables did not affect capital productivity. So the LH coefficient is statistically significant. In other words, this variable has a significant effect on capital productivity. The coefficients of LL, EE and $\mathrm{HH}$ are all significant, so they all affect the productivity of capital. Lagged amounts of capital productivity also have a significant effect on capital productivity.

$\mathrm{R}^{2}$ shows the adjusted coefficient of determination that is $97 \%$ and it reveals that $97 \%$ of the changes in capital productivity are explained by the explanatory variables presented in the model. The statistical value of $\mathrm{F}$ is 33.81 , it indicates that the regression is correct at a probability level of more than $99 \%$ (Table 3). 
Table 3

Results of estimating dynamic model by ARDL method

\begin{tabular}{lllrl}
\hline Variable & Coefficient & Std.Error & T-statistic & Prob \\
\hline Q(-1) & -0.484288 & 0.203563 & -2.379056 & 0.0366 \\
Q(-2) & -0.610449 & 0.241607 & -2.526623 & 0.0281 \\
L & -3.085649 & 2.814284 & -1.096424 & 0.2963 \\
H & -1.140694 & 3.533146 & -0.322855 & 0.7529 \\
E & -5.486141 & 2.914398 & -1.882427 & 0.8665 \\
LE & -0.129111 & 0.530792 & -0.243243 & 0.8123 \\
LH & -8.091899 & 2.648063 & -3.055780 & 0.0109 \\
HE & -0.646304 & 0.837078 & -0.772095 & 0.4563 \\
LL & -2.077708 & 0.915390 & -2.269752 & 0.0443 \\
EE & $-5-0.584173$ & 0.354895 & -2.646001 & 0.0279 \\
HH & -4.616619 & 2.508030 & -1.840735 & 0.0923 \\
T & -0.017638 & 0.011621 & -1.517673 & 0.1573 \\
C & -4.615302 & 6.300198 & -0.732565 & 0.4791 \\
R-squared & 0.973606 & Mean dependent var & 2.495417 \\
Adjusted R-squared & 0.944812 & S.D dependent var & 0.132763 \\
Sam Squared resid & 0.031189 & Akaike info ceiterion & -3.794347 \\
Log likelihood & 58.53216 & Schwarz ceiterion & -3.156234 \\
F-statistic & 33.81323 & Hannan-Quinncriter & -3.625056 \\
Prob(F-Statistic) & 0.000001 & & 2.486188 \\
\hline
\end{tabular}

Source: Author's calculations

The Bundes test is used to test the existence of a long-term relationship between the explanatory and dependent variables of the model after estimating the dynamic equation. As it can be observed, the F statistic has a long-term relationship in the model (Table 4). 
Table 4

Bundes test

\begin{tabular}{lll}
\hline Test Static & Value & K \\
\hline F-static & 3.188178 & 10 \\
Critical Value Bounds & & \\
Significance & 10 Bound & 11 Bound \\
$10 \%$ & 1.76 & 2.77 \\
$5 \%$ & 1.98 & 3.04 \\
$2.5 \%$ & 2.18 & 3.28 \\
$1 \%$ & 2.41 & 3.61 \\
\hline
\end{tabular}

Source: Author's calculations

The long-term relationship of capital productivity is estimated in the agricultural sector after confirming the assumption that there is a long-term relationship between the variables of the model at $5 \%$ and $10 \%$ confidence levels. In the table below, it is observed that the results obtained based on estimating the model and its long-term and short-term coefficients. In this regard, the average energy consumption variable has a significant effect on capital productivity in the long term and the average labor and human capital has no significant effect on capital productivity.

The LE and HE coefficients were not statistically significant, so the two variables did not affect long-term capital productivity. So the LH coefficient is statistically significant. In other words, this variable has a significant effect on capital productivity in the long term. The coefficients of LL, EE and $\mathrm{HH}$ are all significant, so they all affect the productivity of capital in the long term.

\section{Table 5}

Long-term relationship coefficients

\begin{tabular}{lllll}
\hline Variable & coefficient & Std.Error & t-statictic & Prob \\
\hline L & -1.655661 & 1.431151 & -1.156873 & 0.2698 \\
H & -0.797280 & 1.851442 & -0.430626 & 0.6744 \\
E & -3.817260 & 1.454581 & -2.624301 & 0.0222 \\
LE & -0.179001 & 0.266061 & -0.672782 & 0.5138 \\
LH & -4.016697 & 1.052677 & -3.815699 & 0.0025 \\
HE & -0.541826 & 0.414874 & -1.306000 & 0.2160 \\
LL & -1.118546 & 0.380519 & -2.939528 & 0.0124 \\
EE & 0.421137 & 0.169314 & -2.487308 & 0.0286 \\
HH & -1.896045 & 1.139462 & -1.663983 & 0.1220 \\
C & -4.758107 & 3.145964 & -1.512448 & 0.1563 \\
\hline
\end{tabular}

Source: Author's calculation 
Table 6

Short-term relationship coefficients

\begin{tabular}{lllll}
\hline \multicolumn{2}{l}{ Co integrating Form } \\
Variable & Coefficient & Std. Error & t-Statistic & Prob. \\
\hline $\mathrm{D}(\mathrm{Q}(-1))$ & 0.616905 & 0.214208 & 2.879931 & 0.0150 \\
$\mathrm{D}(\mathrm{L})$ & -3.053056 & 1.367696 & -2.232263 & 0.0473 \\
$\mathrm{D}(\mathrm{H})$ & 0.542679 & 1.918207 & 0.282909 & 0.7825 \\
$\mathrm{D}(\mathrm{E})$ & -5.169843 & 1.977435 & -2.614419 & 0.0241 \\
$\mathrm{D}(\mathrm{LE})$ & 0.053472 & 0.390613 & 0.136892 & 0.8936 \\
$\mathrm{D}(\mathrm{LH})$ & -8.201781 & 1.824075 & -4.496406 & 0.0009 \\
$\mathrm{D}(\mathrm{HE})$ & 0.207100 & 0.576217 & 0.359414 & 0.7261 \\
$\mathrm{D}(\mathrm{LL})$ & -1.715561 & 0.716881 & -2.393088 & 0.0357 \\
$\mathrm{D}(\mathrm{EE})$ & -0.636673 & 0.258118 & -2.466600 & 0.0313 \\
$\mathrm{D}(\mathrm{HH})$ & -5.765753 & 1.568054 & -3.677012 & 0.0036 \\
$\mathrm{D}(\mathrm{T})$ & -0.009997 & 0.009603 & -1.041017 & 0.3202 \\
ContEq(-1) & -2.044971 & 0.311364 & -6.567784 & 0.0000 \\
\hline Cointeq & $-(-1.470$ & -0.5466 & -2.6190 \\
\hline
\end{tabular}

Cointeq $=\mathrm{Q}-\left(-1.4730^{*} \mathrm{~L} \quad-0.5446^{*} \mathrm{H} \quad-2.6190^{*} \mathrm{E} \quad-0.0616^{*} \mathrm{LE} \quad-3.8630^{*} \mathrm{LH}-0.3085^{*} \mathrm{HE}\right.$ $\left.-0.9919^{*} \mathrm{LL} \quad-0.2789^{*} \mathrm{EE}-2.2039^{*} \mathrm{HH}-0.0084^{*} \mathrm{~T}-2.2033\right)$

Source: Author's calculations

The error correction model was also used to investigate the short-term relationships between energy productivity and other studied variables. The results obtained are as above table. As can be seen, the error correction coefficient is significant ge and its value is negative. The coefficient value is $61 \%$. This means that $61 \%$ of the variable deviations of capital productivity from its long-term values will disappear after one period. In other words, the results of a policy to be fully adjusted need two years.

\section{Discussion}

In this study, the factors affecting energy productivity have been studied in the agricultural sector during 1990-2016 in Iran. In this regard, energy productivity was first calculated using a partial productivity indicator. The results revealed that energy productivity in the agricultural sector increased by average $1.1 \%$ per year during the study period. The average of labor force per unit of capital and the average human capital per unit of capital is Affectless on the capital productivity, so the average energy consumption per unit of capital effect on capital productivity. 
The study of total energy consumption in the Iran shows that during the period 1990-2012, the final energy consumption has almost doubled and a half, reaching from 403.7 million barrels of crude oil to 99.7 (Arman, 2015). In 2016, the agricultural sector accounted for $3.8 \%$ of total energy consumption. Increasing the share of gas is one of the phenomena that has been significantly observed in the last two decades (Soheili, 2017). Petroleum products in 1990 constitute about $0.93 \%$ of the total energy consumption of the agricultural sector, which in 2016 this share has decreased to $0.65 \%$. This article has both positive and negative aspects. With the increase in the share of electricity and gas in the total energy consumption of the agricultural sector, the share of petroleum products has decreased and reached $0.65 \%$ (Soheili, 2017). On the one hand, it should be noted that with the increase in the share of electricity, the amount of environmental pollution, in the emission of greenhouse gases in the agricultural sector has not decreased, because the source of power generation and electricity are the same fossil fuels (Khalilian and Teymouri, 2016). On the other hand, we do not see the replacement of new energy sources with fossil fuels in the agricultural sector during this period, and therefore environmental costs remain.

This amount of energy consumption is predicted until 2025. For this purpose, first, based on the available information on the value added of the agricultural sector in the period 1990-2012, the amount of this variable for the period 1990-2016 has been predicted. Then, by obtaining the average intensity of energy consumption for the period 1990-2016, the obtained figure has been used as a basis. In the reference scenario, it is assumed that the past trend of energy consumption will spread to the future (Soheili, 2017).

The results of this research are in line with the following research. Khalilian and Rahmani (2016) have examined the factors affecting labor productivity in Iran's agricultural sector. In this study, macroeconomic statistics for the years 1974-2008 have been used. The results show that labor productivity is upward in this sector. Nofarasati (2018) have studied the factors affecting the growth rate of labor productivity in the agricultural sector of Iran during 2000-2020. The study findings showed that the main reason for the increase in labor productivity growth rate can be associated to the relative increase in productivity of total production factors and the effect of total Substitution. Akbari (2013) have measured the productivity growth of total factors of production in the 
agricultural sector of Iran during 1966-2000. The results of measuring productivity growth and output growth showed that the mean growth of productivity and output growth in the agricultural sector during the study period is 2.6 and 4.8, respectively.

The results show that the consumption of fossil fuels has increased sharply and consequently social costs have also increased. Due to the reduction in the intensity of energy consumption, the amount of energy consumption has decreased compared to previous periods and its benefits are found in saving fossil energy consumption and reducing environmental costs.

\section{Conclusion}

According to the study results, it can be said that In Iran, due to the potentials of using solar energy, wind energy, geothermal energy, biomass energy, biogas, etc., there are huge possibilities to replace fossil fuels, the realization of which requires careful scientific and long-term planning. In order to optimize energy consumption and reduce its intensity in the agricultural sector, various strategies should be considered, including saving the use of fossil fuels and using new energies in this sector. Given the current trend of using fossil fuels and their non-renewable properties, as well as the negative effects of consuming such energies on human health and the environment, the need to use new and renewable energy in the agricultural sector seems inevitable. The use of renewable energy is one of the effective ways to create a sustainable agriculture.

Therefore, in order to achieve a sustainable agriculture in Iran, the implementation of energy consumption management policies along with production management, along with regular planning to optimize the consumption of fossil fuels, reduce their current consumption and use of renewable energy seems necessary.

\section{References}

Aghayi, M., Rezagholozadeh, M. (2015). Energy Consumption and Value-Added Growth in Different Sectors of Iran's Economy: Cointegration Approach and Panel Error Correction. Journal of Economic and Regional Development, 22(9), 31-67. DOI: 
https://doi.org/10.22067/erd.v22i9.30393

Ahmadim, Sh. (2013). The effect of technological progress and performance changes on agricultural productivity growth. China economic review, 10(34), 157-174. http://eco.iaufb.ac.ir/article_585186.html

Akbari, N., Mehdi, R. (2013). A study of productivity growth of total production factors in the agricultural sector and its opinion in the fourth development plan, Agriculture development, 50, 59-77. http://aead.agri-peri.ac.ir/article_58884.html

Arman, A., Ruhollah, Z. (2015). A study of the relationship between granular causality between energy consumption and economic growth in Iran during 1985-2005. Iranian Economic Research Quarterly, 7(24), 143-117. https://www.sid.ir/Fa/Journal/ViewPaper.aspx?ID=93554

Azam, M., Khan, A. Q., Bakhtyar, B., \& Emirullah, C. (2015). The Causal Relationship between Energy Consumption and Economic Growth in the ASEAN-5 Countries. Energy Reviews, 47, 732-745. http://ecoj.sbu.ac.ir/article_57453.html

Hatirilig S. A., Ozkan, B., Fert, K. (2005). An econometric analysis of energy input output in Turkish agriculture. Renewable and sustainable Energy Reviews, 9, 608623. http://ecj.iauctb.ac.ir/article_520791.html

Khalilian, S., and Teymouri, A. (2018). Calculation and analysis of productivity in agricultural sectors. Journal of Economics and Agriculture, 2(4), 93-113. https://www.sid.ir/fa/journal/ViewPaper.aspx?id=115296

Khalilian, Sadegh., Rahmani, F. (2016). A study of factors affecting labor productivity in iran's agricultural sector. Journal of Agricultural Economics and Development, 22(1), 23-40. https://www.sid.ir/fa/Journal/ViewPaper.aspx?id=91025

Krueger, A. O., and Tancer, B. (2014). Growth of Factor productivity in Turkish Manufacturing Industries. journal of Development Economics, 11(3), 307-315. https://doi.org/10.1016/0304-3878(82)90009-8

Naji Meydani, A., Mahdi Adeli, M., Arabshahi Deloyi, M. (2015). Investigating the Relationship between Industrialization and Energy Efficiency in the Industrial Sector in Iran. Journal of Economic Policy, 7(13), 27-56. http://ep.yazd.ac.ir/article_552_89f6314fefae7b3221ef770f56c3b48d.pdf

Nofarasti, M. (2018). Unified and collective roots in econometrics. Tehran Rasa Cultural 
Services Institute publisher.

Soheili, K. (2017). The impact of improving production technology in the agricultural sector on the long-term energy demand in this sector using the MEDEE-S economic technical model. Quarterly Journal of Agricultural Economics and Development, 15(60), 70-45.https://www.sid.ir/fa/journal/ViewPaper.aspx?id=80698 